\title{
Forces in Struggle in the Country and the City Today in Brazil: Beyond a Dualistic Understanding
}

\author{
Célia Regina Vendramini \\ Federal University of Santa Catarina, Florianópolis, Brazil \\ Email: celia.vendramini@ufsc.br
}

Received 10 February 2015; accepted 26 February 2015; published 31 March 2015

Copyright (C) 2015 by author and Scientific Research Publishing Inc.

This work is licensed under the Creative Commons Attribution International License (CC BY).

http://creativecommons.org/licenses/by/4.0/

\section{(c) (i) Open Access}

\begin{abstract}
Is it still possible to distinguish the line that separates the country and the city? How do rural and urban workers produce their life today? What are the characteristics that distinguish or approximate them? What movements of resistance have been observed? These questions guide our reflections about the relationship between urban and rural space. Based on a study in the urban periphery and in encampments and settlements of the Landless Rural Workers Movements in Brazil, we seek to understand alternative forms of occupation of space today.
\end{abstract}

\section{Keywords}

Country and City, Informal Work, Resistance, Landless Movement, Neighborhood Association of the Morro Da Cruz

\section{Introduction}

In the 1780s in England the line that separated the city and the country was well defined according to Hobsbawm (1991). In many countries the barrier of taxes, or the old wall around the city divided the city and the the country. Even where there was no rigid administrative division, the inhabitants of the cities were nearly always physically different from the people in the country. We can recall that at the time only London and Paris were large cities. The prosperity of life in the city came from the country.

Nearly a century later, the situation had completely changed; the urban population of Europe exceeded that of the rural areas by 1850. Globally, this ratio was reached only in 2007. Half of the world's population lives in urban areas according to the United Nations ${ }^{1}$, while one-third of these live in slums, favelas and informal set-

${ }^{1}$ UN-Habitat Global Activities Report 2013, United Nations Human Settlements Programme. Available at http://unhabitat.org/. Accessed 1 August 2014. 
tlements with precarious or inexistent urban infrastructure. The more developed countries and Latin America have the highest levels of urbanization, of 74 and 78 per cent respectively.

We thus see the immense extension of regions that are dependent on cities, on industry, commerce, banks, that is, on urban organization as a whole. This urbanization, associated to industrial production, which made it impossible for small farmers to produce their life exclusively from agricultural production, and to the growing consumption of industrialized products, no longer allows identifying a line that separates the city and the country, or urban and rural activities.

As Bernstein (2012) affirms it is not possible to conceive of the rise and functioning of agriculture in modern capitalism without considering the centrality and reconfigurations of new sets of dynamics that link agriculture and industry, and the rural and the urban (the local, national and global).

The centrality of urbanity is found not only in the life of the city, but in the elements that compose it, the access to certain goods, schools and opportunities for exchange, communication and transportation. In 2013, we were witness to various uprisings in cities, such as those in Turkey and Brazil. Young people took to the streets to demand the "right to the city" in Lefebvre's terms. Inspired by the Paris Commune, Lefebvre sees that right as an abstract demand-the right to belong and to determine one's destiny, to not be alienated from the spaces of daily life; and as a concrete demand for social, economic and political goods.

The protests went beyond the cities. Considering the difficulty of small farmers to survive from agricultural work, the rising number of poor rural workers, landless and temporary workers, the twentieth century witnessed various rural uprisings in Latin America.

Given the growing urbanization of life today and the intensification of the interaction of urban and rural space, this paper problematizes what is common and what distinguishes production of life in the country and the city. Distinctions that had a previous logic have become debatable, thus requiring new analyses. Our references are data from field work undertaken in Brazil (in the urban periphery ${ }^{2}$ and in the settlements and encampments of the Landless Rural Workers Movement) and studies that focus on the connection between urban and rural space. The purpose of the article is to analyze a particular reality that expresses social relations on aninternational level. According to Santos (2006), each place is a concrete expression of universality, where people are socially constructing their lives. Space in bourgeois society is the space of capital, of its constitution, affirmation and negation. Therefore, the category entirety is the key to understanding the constant movement in which places are created and renovated in each movement of the society.

Our central focus is on understanding current forms of occupation of space, or of appropriation and domination $^{3}$, and especially on understanding "spaces of hope" (Harvey, 2004). In this light, the category territory ${ }^{4}$ becomes central. Considered as a space of tension, conflict and struggle, subject to the historic process and human action, this category can help us to identify and delineate the social space of possibilities that present themselves as counterpoints to the hegemonic power that controls (but not completely) social life.

\section{The Intensification of the Interaction between Country and City-Literature Review}

The disappearance of the dividing line between the urban and the rural has been observed throughout the world. The transformation that took place in Western Europe in the nineteenth century, when poor landless peasants migrated to cities, has been repeated on a global scale. But the restructuring that would create an industrial-urban order did not become concrete, according to Breman (2009), given that peasants were not able to find secure work and housing when they reached the cities. They became transformed into a vast army of informal workers.

In Brazil, approximately 85 per cent of the population lives in urban centers; in 1956, the income of the industrial sector overcame that of agriculture for the first time. Historically, the Brazilian economy was sustained

\footnotetext{
${ }^{2}$ For Davis (2006), in Third World cities with unplanned growth, the periphery is a relative term specific to the moment: the edge of an urban area one day, bordering fields, forests or deserts, may tomorrow be part of a dense metropolitan nucleus.

${ }^{3}$ According to Lefebvre (1991), there are two modalities of action of human groups upon the natural and material environment: domination and appropriation. They are two opposing and inseparable concepts. The domination of the material nature, resulting from technical operations, demolishes this nature allowing societies to substitute it with its products. Appropriation transforms nature, the body, biological life, time and space given to human goods. Appropriation is the meaning of social life. In this way, the term appropriation does not refer to property, it is a process according to which an individual or group appropriates, transforms into its own good, something exterior.

${ }^{4}$ To understand what is territory and how it is produced, it is necessary to understand the historic and social processes that involve it, given that territory is a political and economic formation that has been historically produced and transformed (see Brenner \& Elden, 2009; Elden, 2010; Quaini, 1979).
} 
by monoculture for export. The country's industrialization took place without agrarian reform, with support or subordination of agriculture (surplus workers for industry and production of foods to keep salaries low in the cities). The agro-export economy served for the primitive accumulation of capital, which financed industrialization. A large part of the population was shifted to the cities, forming a mass of workers available to capital. We thus note that the economic changes and the transformation in production techniques have been accompanied by important movements of the population, such as exodus and migration.

Brazilian agriculture became central to the financialization of the economy, centered on the production of agro-fuels, reforestation (of pine and eucalyptus) for the cellulose industry and other export products: sugar cane is the crop with the highest production value and accounts for 14 per cent of Brazilian agricultural exports, followed by soybeans (14 per cent), beef (10 per cent), grains ( 9 per cent) and other products with temporary cultivation (8 per cent). Agribusiness associates agroindustrial capital with large landowners, in the quest for profit and income from land, with the sponsorship of state policies, accompanied by the demobilization of social forces allied to agrarian reform.

Since this process transcends local, regional and national borders, beyond Brazil, we briefly present information about China and the United States. Agriculture has historically been important in both countries, and both have undergone intense urbanization processes, China much more recently. We observe that the changes in the form of occupation of space are universal, although they occur in stages and with distinct characteristics.

Smith (1997) presents the drama in China, reporting that of 440 million rural workers, nearly 120 million (equal to the total population of Great Britain and France) are unemployed. Chinese authorities estimate that the number of surplus rural workers may grow to 200 million or more at the turn of the century, nearly one fifth of the current population of China. They also affirm that from 20 to 50 per cent of the 160 million urban workers are also surplus laborers.

According to the same author, since the mid 1980s, agricultural income has not been able to keep up with the pace of price increases, especially for agricultural inputs, leading an increasing number of farmers to flee to the cities. During the past 40 years, the country lost one third of its cultivatable land because of agricultural degradation, energy projects, industrial projects and housing construction. In addition, lands have been expropriated from farmers to locate resorts and build dozens of peri-urban roads around the cities.

Harvey (2012) describes the Chinese landscape of overcrowded urban dormitories with a massive surplus labor force mobilized from the poor rural regions that supply migrant labor. The percentage of the country's population that resides in rural areas decreased from 74 per cent in 1990 to 50 per cent in 2010. The populations on the rural margins, which are moving, according to Harvey, illustrate the meaning of Lefebvre's argument made as early as 1960, which the clear distinction that still exists between urban and rural has been gradually disappearing into porous spaces of unequal geographic development under the command of the hegemony of capital and the state.

Using the denominations of "agriculture beyond the farm" and "agrarian capital beyond the countryside", Bernstein (2012: pp. 13-14) suggests the concept of "rural labor beyond the farm", provided not only by "proletarianized" rural workers who are landless and therefore incapable of cultivating the land on their own, but also by marginal farmers or those who are very poor. Both can be locally employed on farms of neighbors (who produce commodities) or seasonally in more distant zones of capitalist agriculture, at times in villages and cities within their countries or even internationally. "Footloose" labor ${ }^{5}$, in Breman's terms, is currently a highly present fact of social life in the rural zones of the global South and expresses the forms in which the types of agriculture are differentiated by class dynamics.

In relation to the U.S. reality, Lichter and Brown (2011) analyze the "new rural-urban interface" and the growing interpenetration of rural and urban American life in recent decades. According to the authors, in 1990, more than 60 per cent of Americans lived in rural areas, including small cities (with less than 2500 inhabitants), rural regions and farms. Today, more than 80 per cent of them live in urban areas, yet more than 50 per cent of them outside the center of the cities. "Conceptually, suburbs represent a rapidly growing associational bridge between big cities and nearby rural communities and the countryside. Suburban residents operate daily on either side of the rural-urban divide; as such, they blur conventional spatial and social boundaries." According to the agricultural Census of 2002, 41 per cent of the farms of the United States and 24 per cent of agricultural lands are located in metropolitan municipalities.

${ }^{5}$ Term used by J. Breman. Footloose Labour. Working in India's Informal Economy. Cambridge: Cambridge University Press. Cited by: Henry Bernstein (2012). 
The new peri-urban reality presents a complex mixture of poor suburbs, which have moved from the urban centers, and where rural workers are also found, attracted by low paying manufacturing and residents of urban centers who move daily to work in agricultural industry (Davis, 2006). Although cities expanded greatly after World War II, it was mainly through suburbanization that surplus labor was absorbed (Harvey, 2012). Thus, an increasing number of poor communities have been expelled to the periphery from the center of the city or from rural areas.

We note that industry today, unlike that of the nineteenth century, as reported by Marx, no longer counts on homogeneous workers, grouped in the same location and organized. It moves to different places, whether urban or rural, seeking to maintain and/or increase its profit rates. If industry is the form of production, especially to capitalist society, it is not specific to the cities, given that it does not remain subdued to place, although it depends on it (Lefebvre, 1991).

The organization of work today is understood by Oliveira (1994) as an "advanced process of cooperation", unlike the epoch of the consolidation of capitalism, in which the separation of the country and the city involved "individual workers, peasants, artisans, those for whom family work produced nearly everything". The production of any product today can no longer prescind collective work, this is what creates the integration between agriculture and industry and the elimination of the separation between country and city.

Lichter and Brown (2011), looking at the United States, consider it obsolete and problematic to establish clear distinctions between rural and urban or present organizational behavior or forms along a rural-urban continuum. Nevertheless, they observe that romantic ideas about the self-sufficiency of small cities and rural areas continue to be disseminated, as well as stereotypes about rural people and families, which see the rural as an antithesis to the modern urban world.

In addition to the idyllic and stereotypical visions of the rural world, traditional and dichotomic visions of the rural-urban interface remain present. This creates the need to grasp the relationship between country and city in a dialectic manner, observing the unity of the elements that compose it and the conflicts between them.

\section{Problems with Daily Life Today: Beyond Traditional Frontiers}

These conflicts that we have identified in the urban and rural realities are reflected in the theoretical field. There is little agreement about what qualifies the country or the city. For Lefebvre (1971), new epochs of socio-historic time are established, and differences appear among the rural era, the industrial era and the urban era, such as: the predominance of rural regions and agricultural production, with their specific relationships of production and their problems; the predominance of the industrial company and its rationality; and the predominance of urban space and its problematic.

Rural life and work, on their own, do not constitute a productive force nor a mode of production, although they are related to the development of productive forces. They sustain themselves and are reconstituted or they disappear-given that they are not eternal or immutable — under different modes of production: slavocracy, feudal, capitalist or socialist. In addition, the rural population is not homogeneous and the expression "peasant class" does not have a precise meaning. The rural population that lives from agriculture combines classes, groups or categories, without constituting a class in and of itself.

We share Vilar's criticism of the concept of "rural economy", which negates the mode of production category and isolates the problems of the rural areas. There is a coexistence between rural areas and the city: the city cannot live without the countryside and places it at its service by complex means (Vilar, 1985). According to Lefebvre (1971), rural life today cannot evolve according to its own laws; it is related in many ways with the general economy, with urban life and modern technology.

One can speak of a rural world, not in the sense that the rural reality constitutes an isolated world, but due to its varied and specific characteristics. For Lefebvre (1971), a dual complexity, which is historic, characterizes rural reality: 1) a horizontal complexity-in the formations and structures of a single historic epoch essential differences are manifest that can create an antagonism; 2) and a vertical complexity-marked by a coexistence of formations of distinct ages and epochs in the rural world today, with the juxtaposition of the most archaic alongside the ultramodern.

Marx criticized the limits of the small rural property, but also criticized the contradictions established by the penetration of the large capitalist agricultural property. He indicated some of the consequences of the revolution 
provoked by large industry in the countryside, which joined the destiny of the urban industrial worker with the destiny of the rural worker and the land itself (Quaini, 1979).

But what are the characteristics that define urban life and rural life? Classic theories of the nineteenth and twentieth centuries maintain that urban life is distinct because of the size and scale of life in modern industrial cities that require specific individual and social adaptations. Later writers have questioned this. Some defend that many of the relationships that appear to define urban life were in fact characteristics of modern life in all its forms. Others maintain that life in the cities still contains much of the intimate character of non-urban ways of life. Some contemporary analysts affirm that there is no distinctive element of urban life. To the contrary, it is in the complex ecology of relations that urban systems are joined, that urban life is defined. We agree with Hutchison (2009) who considers that urban life has been contrasted with the rural or traditional ways of life, although the relevant contrast is increasingly between urban and suburban life.

In the evaluation of historian Williams (1973), the country and the city are changing historic realities, as the interpretations of them. Our real social experience is not only of the country and of the city, in their more singular forms, but of many types of intermediation and new forms of social and physical organization.

In our study entitled "Education and the Production of Rural and Urban Life: Spaces of hope?” (2010-2013), we analyzed educational experiences realized in a rural context (with the Movimento dos Trabalhadores Rurais Sem Terra-MST [Landless Rural Workers Movement]) and in a city (with the Fórum do Maciço do Morro da Cruz-FMMC [The Forum of the Morro da Cruz] neighborhood association) in Brazil, based on the forms of production of life and social organization. In this article we reflect on some common elements of work and life in the country and city, and on opportunities for collective organization.

The empiric work was conducted in encampments and settlements of the MST, located in the states of Paraná and São Paulo, and in peripheral territories of the city of Florianópolis, in Santa Catarina State organized around the FMMC. ${ }^{6}$

For 30 years, the Landless Workers Movement, known as the MST, has been at the front of the agrarian reform struggle in Brazil and has conquered land for 350 thousand families. It is the expression of the historic concentration of land in the countryside, and at the same time, of the most advanced and modern phase of capitalism on the global level, as expressed today by means of agribusiness. The main form of struggle used by the Movement are the occupations of large land areas considered unproductive and the establishment of encampments, in which hundreds or even thousands of families exercise pressure for the expropriation of land. A settlement is established by the formal expropriation of an area by the Brazilian government's National Institute for Colonization and Agrarian Reform (INCRA). Some settlements are organized collectively through cooperatives, associations or other forms of cooperation.

The Assentamento Marcos Freire ${ }^{7}$ (see Figure 1), where some of the fieldwork was conducted, is the result of one of the largest land occupations in the midwestern region of Paraná state. In 1996, more than 10,000 landless people organized by the MST occupied an area of just over 80 thousand hectares, in a region that involved three municipalities. The location, where the land had been held by only one family, came to produce the means of survival for approximately 1500 families.

The MST has also organized workers in the peripheries of cities and established settlements in regions located at the edge of cities. This is the case of the Assentamentos Sepé Tiarajú and Mario Lago ${ }^{8}$ (see Figure 2), located on the outskirts of the city of Ribeirão Preto, in São Paulo state, which is one of the points where the Guarani Aquifer surfaces and is also replenished. The settlements were conceived as Sustainable Development Projects, seeking to implant a system of agroecological production.

The study also involved ten encampments ${ }^{9}$ (see Figure 3), all of which were located in Paraná state: the Acampamento Eli Vive, where the first occupation was in 1991 and the second in 2009, now has 500 families;

\footnotetext{
${ }^{6}$ The study involved a group of doctoral, master's and scientific initiation researchers, including: Natacha E. Janata, Jeferson S. Dantas, Marlene L. S. Sapelli, Thelmely T. Rego, Caroline B. de Azevedo e Fabiane Marra P. da Silva.

${ }^{7}$ The study at the Assentamento Marcos Freire was undertaken by Natacha Eugênia Janata, under our supervision, for her dissertation, entitled: “Juventude que Ousa Lutar!”: Trabalho, Educação e Militância de Jovens Assentados do MST, UFSC, Florianópolis 2012.

${ }^{8}$ The study was conducted by Thelmely Torres Rego (2011), under our supervision, for her thesis entitled: A Formação Técnico-Profissional em Agroecologia no MST/SP, UFSC, Florianópolis.

${ }^{9}$ The study at the encampments was conduted by Marlene Lucia Siebert Sapelli (2013), under our supervision, for her dissertation entitled: Escola do campo-espaço de disputa e de contradição: análise da proposta pedagógica das escolas itinerantes do Paraná e do Colégio Imperatriz Dona Leopoldina, UFSC, Florianópolis.
} 


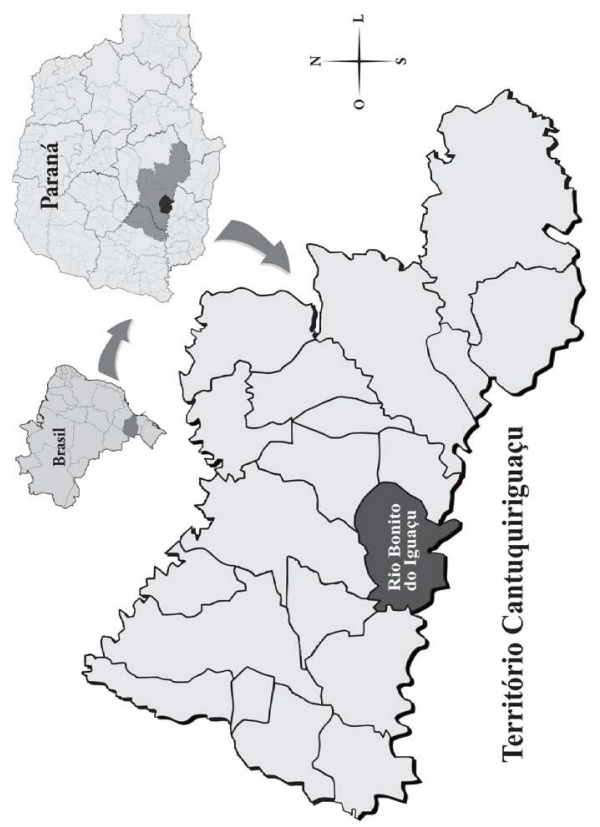

Figure 1. Location of Rio Bonito do Iguaçu, Paraná. Source: Condetec. Território cantuquiriguaçu: estratégia para o desnvolvimento II. Laranjeiras do Sul, 2009. Adaptation of Jeasir Silva do Rego.

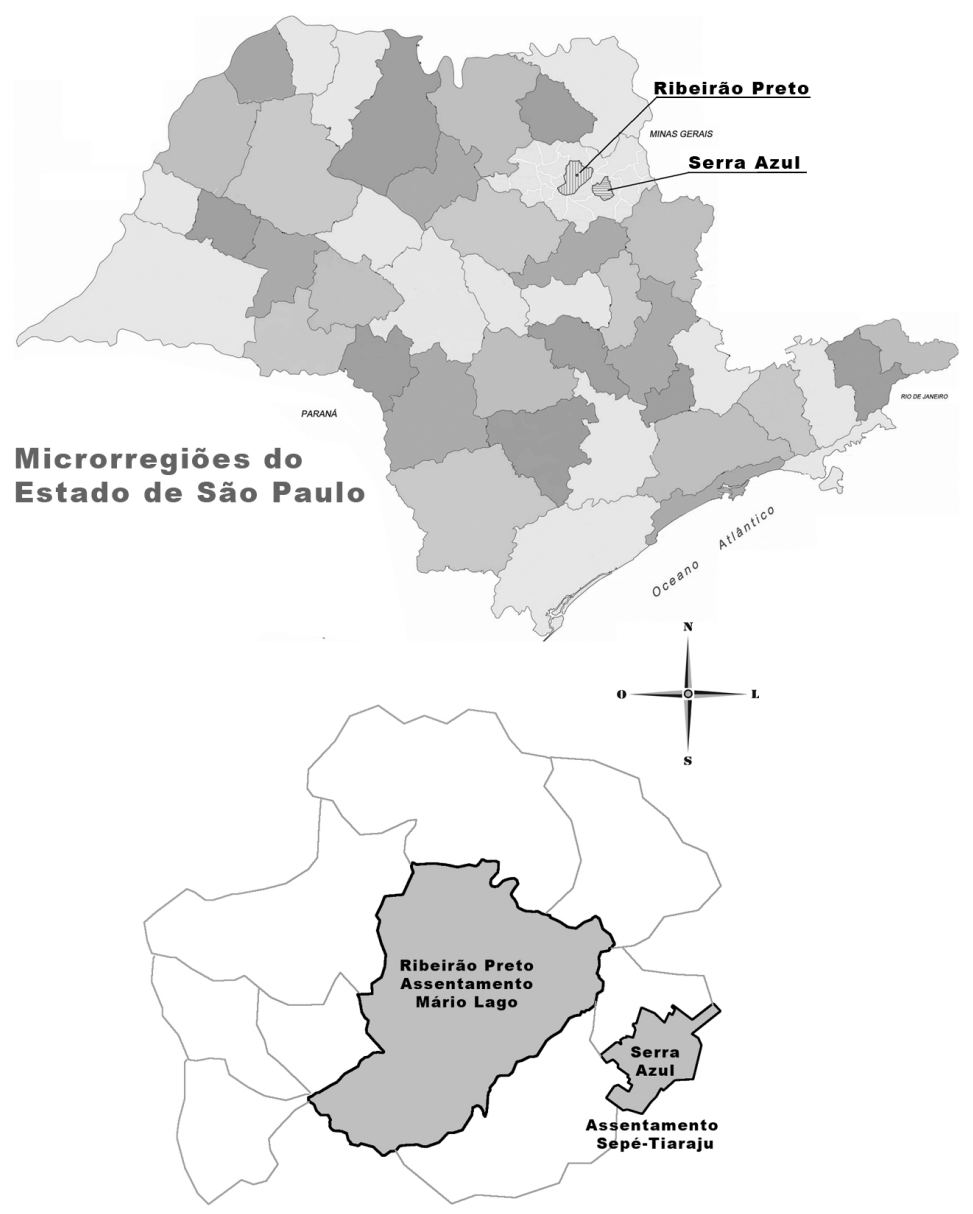

Figure 2. Location of Mario Lago and Sepé-Tiarajú Settlements-São Paulo. Source: Prepared by Jeasir Silva do Rego. 


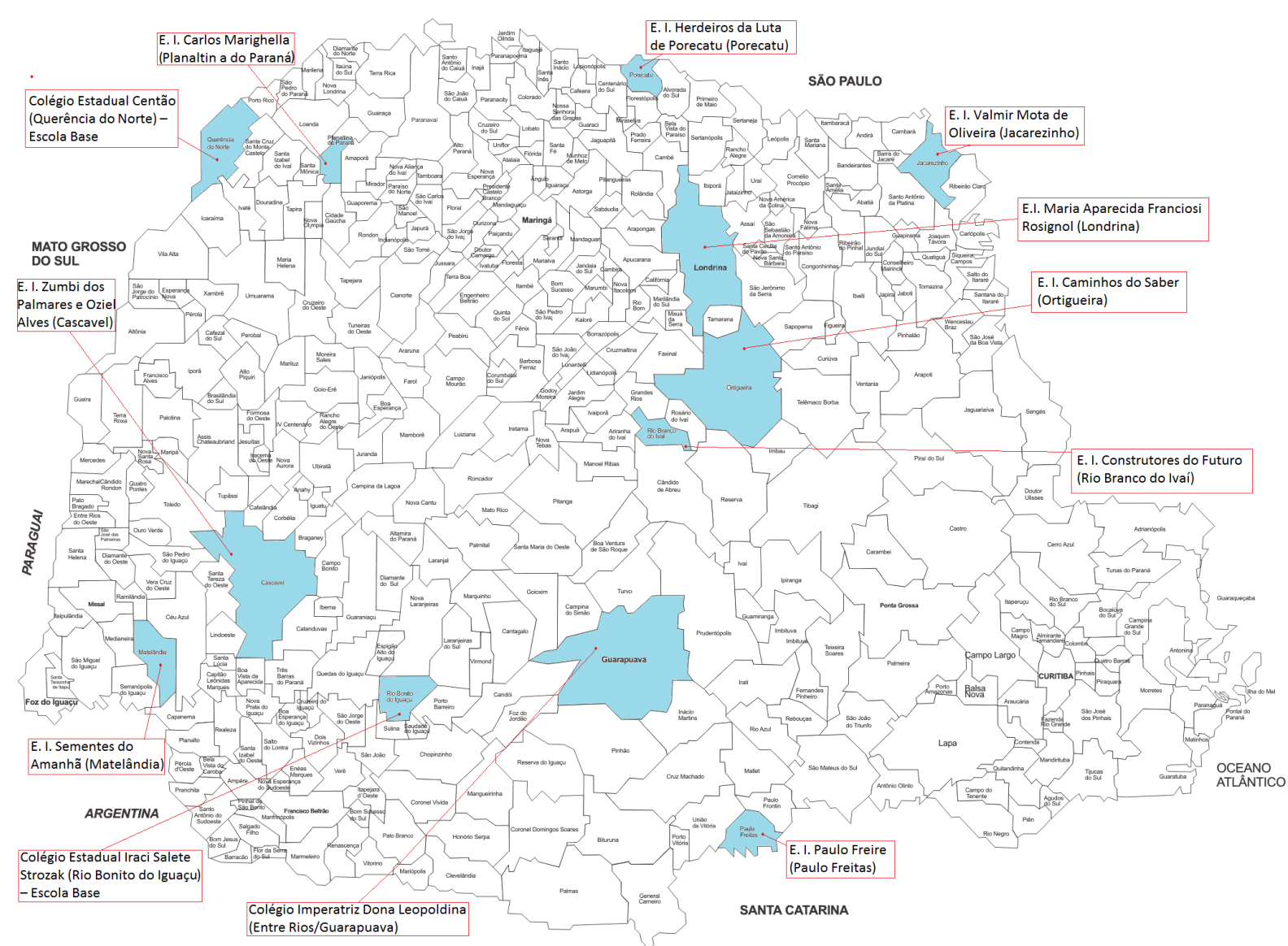

Figure 3. Location of encampments schools, Paraná.

the Acampamento Casa Nova, where 35 families have lived since 1997; Acampamento Maila Sabrina, the result of occupations in 2003 by approximately 500 families; Acampamento $1^{\circ}$ de Maio, from an occupation in 2003, which now has 35 families; Acampamento Dorcelina Folador, constituted in 2004 with about 95 families; Acampamento Chico Mendes, the result of an occupation by 800 families in 2004, which has dropped to 100 families; Acampamento Elias Gonçalves de Meura, located in a region of Parana that has 16 settlements (this encampment was the result of an occupation by approximately 400 people in 2004 that became violent, leading to various injuries and the death of Elias Gonçalves de Meura); Acampamento $1^{\circ}$ de setembro, from an occupation in 2007, which is now called the Pré-Assentamento Egídio Brumetto, with 190 families; Acampamento Valmir Motta de Oliveira, from an occupation in 2008, the area was expropriated and is in the process of formation of the Assentamento Companheiro Keno, with 100 families; and finally the Acampamento Herdeiros da Luta de Porecatu, the result of an occupation in 2008, where 150 families are now living.

In relation to the city, the study was undertaken in territories on some of the hillside neighborhoods (see Figure 4 ) in the center of the city of Florianópolis (most of which are on an ocean island) ${ }^{10}$ with a population of about 30 thousand, about 8 per cent of the total population of the city, which is the state capital. This ample labor force, which mostly came from rural areas, works largely in civil construction, domestic services and other informal service jobs.

In the late 1980s, when the irregular and unorganized occupations in Florianópolis became more pronounced in its peripheries, the social experiences that occurred on the hillsides of the Santa Catarina capital were supported by the Landless Movement, which helped the new residents adapt its forms of struggle to the city, especially occupation. As a result of previous historic experiences linked to the migratory problematic, regularization

\footnotetext{
${ }^{10}$ The study was conducted by Jeferson Silveira Dantas, under our supervision, for his dissertation entitled: Espaços coletivos de esperança: a experiência política e pedagógica da Comissão de Educação do Fórum do Maciço do Morro da Cruz em Florianópolis/SC, UFSC, Florianópolis 2012.
} 


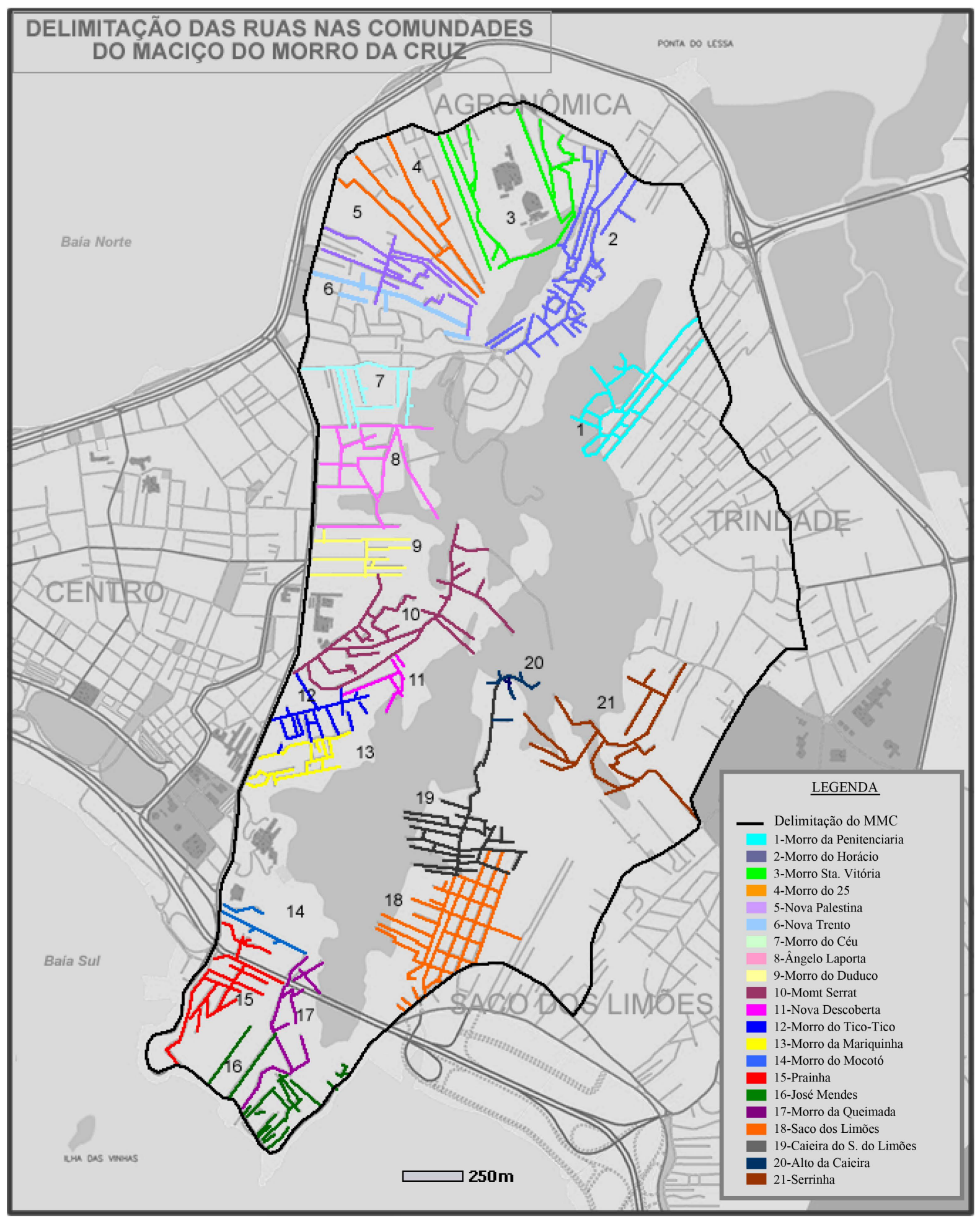

Figure 4. Location of territories of Maciço do Morro da Cruz-Florianópolis/SC. Source: Henning, Luciano A. A distribuição espacial dos alunos das escolas integrantes da Comissão de Educação do Fórum do Maciço do Morro da Cruz. Florianópolis, Universidade Federal de Santa Catarina, 2007.

of land ownership for the landless and the political organization of fishing communities and small farmers, the Neighborhood Association of the Morro da Cruz was established, as an alternative to the community centers 
created in the 1970s by the state government. The FMMC was strengthened in the second half of the 1990s, mainly in work related to discussing and taking actions against drug trafficking.

Based on elements of rural and urban reality presented above, we reflect about the three common categories in the lives of workers today: unemployment and informal employment; the mercantilization and homogenization of life; and resistance. We consider that these categories express current social relations, although they are historic and permeated by contradictions.

\subsection{Unemployment and Informal Labor}

Considering that work is the primary means of social insertion in the current capitalist mode of production, the absence of workforces people to move beyond local, regional and even national borders. This movement has been constituted as a "solution" within a mode of production that has been incapable since its origin to absorb the entire available labor force. Nevertheless, we know that the solutions created by capital for its own crises are neither eternal nor absolute.

And what are the alternatives created by workers, individually or collectively? How do poor rural and urban workers survive today?

The long wait for settlement by some of the landless who were in encampments, at times for more than ten years, the constant evictions, the itinerary life and the "provisory" situation, led them to seek alternatives to survival in temporary, precarious, insecure and informal labor. Many work in cities in domestic services and civil construction receives from US\$20 - US\$30 a day; or as daily workers on neighboring farms, in planting and collecting sugar cane, coffee, tobacco, cassava, on poultry and hog farms and others, receives some US\$10 US\$20 a day, according to data collected in our study.

In the camps, they produce foods for their own consumption and raise animals, at times they sell products through the federal government Food Purchase Program, or sell them in the cities. Some families receive government food assistance known as a "basic basket" every three months. In addition, they benefit from the solidarity of already settled workers. In some better organized encampments, there is collective and agroecological production and few work away from the land. On the other hand, there are encampments with quite precarious living conditions and with a lack of work opportunities, due to a mechanized monoculture in the surrounding region.

In this process, many landless workers linked to the MST are submit to super exploitation of their labor, in terms of an absence of contracts, the amount paid for a day of work, the lack of benefits called for by labor laws, working conditions and transportation. Our study found that in the early all work conducted away from the encampment, by those living in the encampments, is done informally. This is the case of women who do domestic work and men who do temporary farm work, in construction, in harvest or planting in raising animals or other jobs.

The reality of the encamped landless is very similar to the situation of many workers in Brazil, according to data from the Interunion Department of Statistics and Socio-Economic Studies ${ }^{11}$ in 2009: 41.7 per cent of those engaged in agricultural activities worked in temporary farm work; only 16.8 per cent of rural workers had a permanent job; 83.6 per cent of rural workers did not make social security payments; the average monthly income of the rural workers was US\$230 for men and US\$220 for women.

Moreover, some workers are still found in conditions considered equivalent to slavery and in 2010, 2628 workers were freed in 209 inspections on farms. There were nearly eight million children and adolescents from 5 - 17 working in Brazil and most in rural areas, where 77 per cent work in non-paying activities, mostly agriculture (OIT, 2001).

The situation changes, but not substantially, when the landless win access to land and establish settlements. In the case of the Assentamento Marcos Freire, production is organized individually by the 578 families. The production is largely for their own consumption, including fruit, vegetables and animals (cows, poultry and hogs).

Some of the families raise tobacco in an integrated system controlled by the only company present in the municipality, Universal Leaf Tabacos, a U.S. based company that is a world leader in sales of tobacco leaves and processed tobacco. Production of vegetable charcoal is a complementary source of income. The presence of the tobacco company, as well as the leaseholding, reveals the contradictions and the limits of agrarian reform in the country. The difficulties in access to financing, the precarious living conditions in which the families remain,

\footnotetext{
${ }^{11}$ Estatísticas do meio rural 2010-2011, MDA, Brasília 2011.
} 
even after the establishment of the settlement, lead them to look for individual solutions for survival.

Of the 452 students at the Colégio Iraci Salete Strozak, which serves children and youth at the Assentamento Marcos Freire and other neighboring settlements, 419 come from families that receive financial support from the Brazil's flagship Conditional Cash Transfer (CCT) program, the Bolsa Familia [Family Grant], which helps to keep the youth on the settlements, at least until they complete high school.

Since 2010, an agreement between the association of the settlement residents with INCRA has stimulated milk production and planting of other crops, as well as training and education of farmers in the settlements, guidance in production and sales.

In the two agroecological settlements in the Riberão Preto region of São Paulo (Sepé Tiarajú and Mario Lago), where the students of Integrated Agroecological Technical High School, we note that the difficulties persist. They are related to the lower quality or insufficient quantity of the lands dedicated to agrarian reform, the lack of funds for investments in production and often the absence of technical knowledge. Added to this reality is the delay in the implementation of settlement projects by government agencies, revealing that agrarian reform continues to be a partial social assistance policy, instead of a concrete opportunity for "redistribution of wealth in rural areas" (Germer, 2007).

According to questionnaires given to youth in the technical course, 59 per cent of the students' families from the metropolitan region sell their labor (75 per cent of them do temporary work) and work in agricultural production on their own settlement. And 56 per cent of the families that sell their labor come from the rural area. Among the work conducted today by their parents, in addition to agricultural production, there are activities such as: construction, commercial sales, lumbering, domestic work and others. The uncertain and precarious working conditions precede the entrance in the settlement and persist within it.

The national Study of Education in Agrarian Reform (PNERA), conducted in 2004, specifically in regions of agrarian reform, showed that in São Paulo state, although the main source of income of the settled families was crop production, livestock or extraction (73 per cent), 11.6 per cent of the families had wage work as their main source of income, both in the rural areas and in the city and 12.3 per cent depended on income from social security. ${ }^{12}$

According to the same study, the settled families have sources of income not related to agricultural production, whether this is the main source of income or not. The study revealed that 62.3 per cent of the settled families in the state affirm they have another source of income beyond farm production and, among the information from the study, we highlight: 28.9 per cent have salaried income, 10.2 per cent income from independent jobs, 25.7 per cent from social security and 29.4 per cent from other government programs, in addition, 4.8 per cent earn income by processing their production, 2.1 per cent from renting property or equipment, and 0.5 per cent from other sources not identified in the study.

Concerning the residents of the peripheral areas of the city of Florianópolis, especially the Morro da Cruz, only 20 per cent are from the municipality and neighboring cities, 70 per cent migrate from rural areas in the interior of the state and another 10 per cent come from other states in the country. The rate of population growth on the hillsides of the Morro da Cruz is double that of the regions of the city with more complete urban infrastructure. The lands on the hillsides are sought by real estate developers, and with the support or omission of government, residents of the hillsides have been evicted from areas far from downtown (Dantas, 2012).

The jobs of the hillside residents are precarious and temporary, with extremely low salaries, with construction the largest employer of male labor (the men work as masons, construction assistants, carpenters, electricians); while domestic labor is what most occupies female workers. Less than half of those who work have signed working papers and more than 30 per cent are unemployed (Op cit).

Our study issued 154 questionnaires, including 113 to high school students and 41 to intermediary students at the Padre Anchieta School, which serves these poor regions of Florianópolis, SC. We found a high number of students born in other states, which indicated a change in the local population, which was now constituted mostly by people coming from other municipalities within the state. The students indicated the search for jobs and housing as possible reasons that their families moved to the hillsides.

Mothers represent the highest number of economically active family members with signed working papers, followed by fathers and other family members including the students. The areas of work in which the families are inserted include domestic jobs, sales, government and construction.

The study thus identified common elements among families in encampments and settlements and those on the

\footnotetext{
${ }^{12}$ Statistical synopsis of Pesquisa Nacional de Educação na Reforma Agrária-PNERA 2004, INEP, Brasília.
} 
hillsides of Florianópolis in terms of the labor strategies of these poor workers. The roots of poverty were thus increasingly shared among rural and urban areas. According to Harvey (2012), more than 2 billion people in the world live on less than US\$2 a day. This leads to the conclusion that the problem of global accumulation of poverty cannot be confronted without confronting the obscene inequality that has accompanied the accumulation of global wealth.

To mitigate poverty, many Brazilian families depend on government assistance, like the "basic basket" or the Bolsa Família Program. The Agricultural Census of 2006 confirmed that agricultural income was complemented both by work off the property, as well as by retirement pay or other social programs, which allowed people to remain in rural areas. Of the 39 per cent of farmers who declared that they had some income that was not from activities on their properties, 47.73 per cent mentioned retirement pay and pensions, 34.91 per cent income from special government programs, in addition to 31.66 per cent who received salaries obtained in other activities. ${ }^{13}$

Informal, insecure and precarious work ${ }^{14}$ is increasingly constant among workers. The global informal working class, with nearly one billion people, as emphasized by Mike Davis, constitutes the social class with the fastest and most unprecedented growth on earth. Informal survival is the new and principal way of life of the majority of people in the cities of the so-called Third World. Davis uses the document "Slums of the World: the face of urban poverty in the new millennium?” from the Global Urban Observatory (2003) as a source, which identifies informal workers as two-fifths of the developing world's economically active population. The same document cites studies that indicate informal economic activity responds for 33 - 40 per cent of urban employment in Asia, 60 to 75 per cent in Central America and 60 per cent in Africa. Davis (2004: pp. 209-210) also cites the Inter-American Development Bank as a source, according to which the informal economy currently employs 57 per cent of the Latin American labor force and offers four of five new "jobs".

This context has pushed large population contingents in different directions. There are no territorial, cultural or language barriers to the search for survival. Mobility has been growing and has changed or reinvented many cities and also the countryside. In addition, it has contributed to breaking down borders that still remain between the rural and urban, concentrating workers around cities, or in peri-urban space. More than an opposition between country and city, we can now speak of opposition between center and periphery or between urban and suburban life.

The return to the countryside has been promoted by the Western media as an option in these difficult times of crises. The supposition is that a large number of rural migrant workers once dispersed to the cities can return to the country and be absorbed in agricultural work. Jan Breman (2009) reveals in his study in Java, Indonesia that migrants do not return to their villages because they lack land or other forms of capital.

Nevertheless, some workers opt for collective survival strategies, as is the case of the landless organized in the MST in Brazil. We note that those in encampments and settlements that strive to organize production collectively have had greater success in economic and political terms.

\subsection{Mercantilization and Homogenization of Life}

We agree with Harvey (2012: pp. 128-129), who understands that the dynamic of class exploitation is not confined to the workplace and the class struggle is not limited to the factory. The effects of secondary forms of exploitation (by dispossession, expropriation, deprivation by owners of land and houses by speculators) are felt primarily in the space of life and not in the factory. When workers spend their salaries and other benefits, such as bonuses for transportation, meals, or housing, for example, the income is recovered by the capitalist class as a whole, by merchant capital and the owners of houses and lands, by bankers and financiers, by those who negotiate (traffic) in credit.

According to Harvey, the production and reproduction of urban life, even if some workers may be "unproductive" according to Marxist criteria, they are nevertheless socially necessary for the reproduction of the relations of class between capital and labor. As we affirm above, many workers are temporary, occasional and itinerants and many frequently disguise the supposed border between production and reproduction.

In the case of the encamped landless workers, those who live in tents and shacks, they do not have access to basic infrastructure in terms of housing, water supply and electrical energy or to healthcare, transportation and

\footnotetext{
${ }^{13}$ Censo Agropecuário 2006, IBGE, available at www.ibge.gov.br. Accessed August 1, 2011.

${ }^{14}$ This type of work is characterized by casual and fluctuating employment, at home, in factories or as autonomous workers, in the open air, in the absence of any contractual or labor rights, or collective organization (Breman, 2009: p. 29).
} 
other services. Few encampments have electrical energy, some have their own generator for collective spaces, others use lights run by batteries. Water comes from streams and reaches the tents by hose. Of the encampments in this study, the Maila Sabrina was the one with the best living conditions. One factor responsible for this was the availability of land to cultivate, as well as the organization of the families. In contrast, the Acampamento Herdeiros da Luta de Porecatu was that with the most precarious living conditions, some tents were built over the former municipal garbage dump, leading to illness among the residents. In addition, the water was contaminated by chemicals used in the neighboring sugarcane plantations.

All of the encampments had a school (for the elementary grades) and sought to teach the children within the political and pedagogical principles of the MST ${ }^{15}$. The struggle for the school is present in the trajectory of the Movement since its first encampments in the 1980s, and the MST has sought to provide schooling for children and youth in the encampments and settlements, as well as constitute them as formative spaces in the realm of the struggle for agrarian reform and social transformation.

The settlements have better living conditions than the encampments, although their residents continue to face problems of infrastructure, and must constantly organize to demand access to government programs. In the Assentamento Marcos Freire, the residences have not been concluded for a number of reasons, including the limited initial funding from the National Institute for Colonization and Agrarian Reform (INCRA) of approximately US\$1250 dollars, and restrictions that allow them to only purchase construction materials from stores indicated by the Institute, which raises the price.

Access to healthcare is precarious, with only one municipal health clinic in the settlement, which only operates during the week. In cases of emergencies on weekends, it is necessary to go to the municipal center, which, for the most distant communities, is about 46 kilometers away. The lack of access to communication aggravates the problem, given that there is no landline or cellular phone service.

Due to the poor road conditions, access to the settlement is limited on rainy days. Some families have cars and some young people have motorcycles, individually facilitating transport. Horses still serve as a means of transportation. There are private bus lines that make the route from some communities to the municipal center, but only once a day during the week. School transportation, which is free, and comes to all the communities, is often used.

The Iraci Salete Strozak state school serves children and youth from the settlements in the region, which include approximately 1500 families. The school has an important relationship with the MST and its principles of struggle, which is indicated in the choice of the school's name ${ }^{16}$, its educators, the curriculum and other elements. This relationship between a state institution and the MST, or between the MST and the teachers (although some do not identify with the MST) and the community, is permeated by many tensions and conflicts. The educational aspects that distinguish the Colégio Iraci in the education of the young people are: in addition to access to knowledge and the development of artistic and expressive skills, concepts of self-organization and ties with the social reality emphasized by the MST (Janata, 2012).

In relation to life on the hillsides of Florianópolis, chronic problems remain unsolved. In addition to a lack of drinking water and sewage and garbage collection, the hillsides suffer from a precarious and inefficient public transportation system that is nonetheless very costly for the users. The streets and alleys are full of ruts and sewage runs freely. They are steep and difficult for the elderly. There are many recent and irregular occupations without electricity and drinking water; infrequent or non-existent garbage collection; precarious or inefficient healthcare; in addition to the prejudice that residents of these territories commonly face when seeking work, schooling and government services.

According to the questionnaire answered by the students in our study, the main elements absent in the locations where they live are: parks and other areas of public leisure; sewage treatment and a health clinic.

The level of schooling is low among the adult population; about 70 per cent are able to partially or completely finish elementary school. The children and youth of the hillsides of Florianópolis face various problems, from the closing of three public schools in the past six years, the poor physical conditions of many schools, as well as the lack of financial resources and materials, the high turnover of teachers, as well as students who do not pass and or abandon school. These factors are probably related to a decrease in the number of students in recent years

\footnotetext{
${ }^{15}$ The educational principles of the MST are based on the articulation between the school and its contents with the work and struggle of landless workers, which are present in the development of the Pedagogical Policy Project for schools, which involves community and articulates aspects of labor and production in the organization of the school; in the establishment of collectives of educators in the schools; in the organization of educational moments, which combine time for study and time for work; and in the self-organization of the students.

${ }^{16}$ The name of the school is a tribute to the MST leader and educator Iraci Salete Strozak, who died in a bus accident in 1997.
} 
and poor attendance at high schools, especially in the night programs, disturbing developments that our study is attempting to understand.

Nevertheless, the organization of the administrators and teachers of the schools in conjunction with the Education Commission of the Neighborhood Association of the Morro da Cruz has been an important experience. The commission works on pedagogical projects for the schools, the preparation of educators and various other actions to confront the environmental and social problems of that territory.

The living conditions in urban peripheries of England in the 1800s, which were inhabited by a large number of migrants from the countryside, were reported in detail by Engels (2009) who discussed housing, nutrition, health and education. We note the persistence of the same living conditions among the working class, which continues to be exploited and dispossessed by capital. There is an urban crisis in Brazilian cities, provoked by the current context of financial capitalism (Maricato, 2006). The broad social protests that exploded throughout the country in June 2013 are the expression of this urban crisis, with demonstrators making many references to the high cost of transportation and the poor quality of public services as a whole. The cities are marked by a concentration of poverty in the peripheries, by violence, by an absence of public infrastructure and by increased unemployment. In this way, we agree with Harvey (2012) that capitalist urbanization perpetually destroys the city as a commons.

There are few differences in the living conditions of the impoverished population in the countryside and in the urban periphery in terms of access to government programs, such as healthcare, transportation, education and leisure. Urban residents live in spaces that usually have better infrastructure, hospitals and schools at all levels, although the majority only has access to poor quality schools and healthcare. In addition, they commonly face problems related to violence. Drug trafficking, for example, is one of the most serious problems on the hillsides of Florianópolis.

Meanwhile, environmental problems affect the population as a whole in different manners. In the case of the urban peripheries, people are more exposed to garbage and sewage, in addition to noise and environmental pollution. In the periods of intense rains, there is a high risk of landslides on the hillsides. In the rural areas, the exposure of workers to agricultural pesticides and herbicides has caused various diseases. In addition, families increasingly consume low quality industrialized products, without nutritional value, even families who live on farms.

We also note an impoverished cultural and social life in which families spend their little free time in front of the television. This is caused by a number of factors, including the fact that most people are tired or even exhausted when they get home from work, the fantastic power of the media, the lack of access to cultural goods, the absence of public spaces for meeting and leisure, and few cultural and social alternatives. Harvey (2012: p. 105) has shown how each city loses its mark of distinction, given the homogenous international mercantilization and commercialization of all things. The urban and the rural become places of consumption.

Because some of the encampments and settlements studied lack electricity (and thus do not have television), and because they are much less violent and organized around a social movement, there is greater interaction among people, in addition to the fact that the residents are engaged in joint efforts to demand access to government programs. The territories of the Morro da Cruz still have fragile levels of social involvement, although they are found in the same situation as the encampments in terms of the absence of qualified government programs for healthcare, education, urbanization and sanitary conditions. Ethnic and racial conflicts and gang fights over control of drug dealing areas add to the complexity of social relations challenging any pretense of political or administrative unity of these territories.

\subsection{Resistance}

Lefebvre refers to contradictions and negativity associated to abstract space in the context of the capitalist mode of production, which "carries within itself the seeds of a new kind of space. I shall call that new space 'differential space', because, inasmuch as abstract space tends towards homogeneity, towards the elimination of existing differences or peculiarities, a new space cannot be born (produced) unless it accentuates differences”. Further, he understands that only class struggle can prevent abstract space from extending throughout the planet, erasing differences (Lefebvre, 1991: p. 52).

Harvey (2012), meanwhile, uses the concept of heterotopy. This concept delineates social spaces where something different is not only possible but essential to the definition of revolutionary strategies. He affirms that hegemonic power cannot entirely control urbanization. By intensifying contradictions within a rapidly accele- 
rating and frequently uncontrollable urbanization process, it creates a set of interstitial spaces in which all kinds of libertarian and emancipatory possibilities can flourish. He thus recognizes various anti-capitalist movements, which are stronger in some places than in others, at the interstices of the unequal space-time development of capitalism (Harvey, 1996: p. 420, 430).

Various struggles today, in various parts of the world and with different forms of organization and demands, appear to question what Lefebvre calls abstract space, or the space of capital. These struggles develop in contexts of strong hostility and repression. This is the case of the land occupations and encampments of the Landless Rural Workers Movement in Brazil; the factory occupations in Argentina that have led to cooperative management; the rebellions in Bolivia against neoliberal privatization-such as the famous "Water War" of 2000; and other struggles over the use of natural resources; the many resident associations in cities that organize to provide collective goods; struggles for food sovereignty to counter large agribusiness in various countries and continents; historic indigenous struggles in defense of land, culture and conditions for production of life; immigrants who seek to preserve their identity, many through campaigns for decent salaries that allow survival in the metropolises; the Occupy Wall Street movement in New York City and similar protests in other cities.

Struggle is the central element of life in the MST encampments, unlike the settlements, in which work becomes the central need. The landless in the encampments are joined together and organized to win a right to land. Therefore, the challenge that is presented is the ability for collective organization, resistance and mobilization to achieve their objectives. The families are organized in committees (commissions for food, health, safety, hygiene, education, organization), base nuclei and brigades (groups of neighboring families within the camps) ${ }^{17}$, in addition to the coordination of the encampment. Nevertheless, given the long "wait" for the settlement, the encamped must produce at the encampment and or work in other agricultural and non-agricultural activities.

The settlements are spaces of production and socialization of families of workers who can no longer produce their lives on small farms, through lease holding, sharecropping or by performing rural or even urban salaried work. Their life trajectory leads them to conclude that collective organization is their best option for survival, led by the Landless Movement (MST), in the case in study.

Some settlements adopt the challenge of producing their existence in a collective or cooperative manner, or through agroecological production. They thus establish "social laboratories" that experiment with other forms of organization that are different from and are a counterpoint to capitalist exploitation. Nevertheless, they are not immune to various forms of capital control, whether commercial, industrial or financial. This establishes the need to insert these experiments in a larger strategy of working class struggle and an alternative social project.

The concern for the education of youth and of new militants, as well as the schooling of children and youth, has a significant presence in the trajectory of the MST. The itinerant schools, located in the encampments, and the schools of the settlements, oriented to a project of omnilateral education ${ }^{18}$ are constructing processes of self-management and self-organization and are concerned with the relationship between school, work and life. In this process, many contradictions arise, especially the distance between what is proposed and what is realized, given the limits created by society and the capitalist educational system.

Some of the MST's schools and political and professional education centers have established themselves as important sources of strength that struggle against capital in the education of youth, in particular, those who are activists. ${ }^{19}$ The technical-professional courses in agroecology, for example, seek to provide an education that responds to the needs of the settlements in terms of production, schooling and inserting the young people in

\footnotetext{
${ }^{17}$ The base nuclei are usually composed of about 10 families, which together form brigades of 50 families, which compose the regional brigade of 500 families (the MST recommends that the Base Nuclei and Brigades always have a man and woman in the coordination). There are collectives that come together in different moments to discuss issues, make decisions and execute local, regional and national actions. The sectors are organized with representatives of these groups to care for specific issues, such as healthcare, discipline, communication, production, education, culture, gender and others at the encampment, at the regional state and national level (MST, 2005).

${ }^{18}$ Marx described omnilateral education as that aimed at the development of the universal potentialities of human beings, in all senses, the faculties and productive forces, needs and the capacity to satisfy them.

${ }^{19}$ The trajectory of the MST includes three core issues that have been focused on in the fight for education: struggles for social change, the relationship between work and education, and professional training. There are several educational experiences that reveal the MST's success in this field: 1) the Florestan Fernandes National School was built and maintained through volunteer work and is a space for political education and a training center for several states. It is located in Guararema, São Paulo state; 2) the Josué de Castro Educational Institute is an autonomous school that offers training courses for teachers, health workers and managers of cooperatives, located in Veranópolis, Rio Grande do Sul state; 3) the itinerant schools in MST encampments that have invented a new way of learning and teaching in movement; 4) the schools located in the settlements that teach in conjunction with the farm work and rural life of the settlers and finally; 5) the undergraduate and postgraduate studies in partnership with universities that promote a flow of young workers to the best public universities in the country and create important relationships between MST members and a diverse student body of college students.
} 
agroecological work.

Meanwhile, the residents of the hillsides of the city of Florianópolis, in our study, constitute a vast and varied population, apparently with little in common. Nevertheless, their trajectory and living conditions reveal common experiences of expropriation and exploitation. Most of them have been moving from the country to the city, from cities of the interior to the capital, from other states to Santa Catarina, etc., that is, they "wander through the world", in the words of Hobsbawm, in search of survival.

In this process, they seek individual and collective alternatives to the production of life. The Neighborhood Association of the Morro da Cruz constitutes a collective possibility for bringing together residents of the hillsides to confront chronic problems such as drug dealing, violence and the absence of state policies. Their political trajectory, however, is permeated by many contradictions, such as the relationship with state power, the personification and cooptation of leaders and the strengthening of NGOs, which attenuate the radical nature of the collective struggles and occupy the spaces of organized social movements.

It is not easy to distinguish between reformist and revolutionary initiatives in the urban and rural environments. The struggles of the MST, unlike those of the FMMC, are imbued in a broader political project. They have advanced in their ability to articulate their struggles with those of other sectors of rural workers (salaried, temporary, migrants...) and with urban workers. We understand that the construction of ties between the two spaces is crucial.

\section{Conclusions}

What is there in common between the forms of production of life and wealth in the country and the city? We have apparently emphasized the particularities of each space. Nevertheless, there is an essential element in common, collective work and the production of surplus for capital. Small farmers and capitalist companies are articulated to the same production chain, even if in completely unequal forms.

According to Williams (1973), what oil companies do is the same as what landowners do. And many others have followed the same route, seeing land and its properties as available for profitable exploitation. There is a qualitative difference between the product of agriculture and that of the mine or of industry, but if we see only the contrast, we see only some of the results. The effects of the human establishments, and the common and or locally self-organized ways of life are often very similar. Williams affirms that the relationship between industry and agriculture, and that between the country and the city, are the mediated products of a set of decisions about capital investment taken by the minority that controls capital and that determines how to use it through the calculation of profit.

In addition, everyone in some way becomes a consumer of industrialized products that are controlled by large and powerful transnational companies, such as seeds, fertilizers, machinery, food, clothes, and much more. The term industrialization cannot be understood only "as creation of industrial activities in places”, but in its broader sense "as a complex social process", which encompasses the expansion of consumption, the constitution of broad markets and the actions that integrate them and drive social relations (Santos, 1994: p. 27).

The details of each location are different, as is natural considering cultural differences, but many of our historic experiences are essentially similar, as are the forms of capitalist development, although they take place with different characteristics. Capitalist industrialization in Brazil, for example, is quite different from the classic English experience, but at its essence, it is guided by the same organizational logic.

This article analyzed elements referring to work and living conditions in the countryside and urban periphery, which expressed different forms of control of production and reproduction of life by capital. Therefore, we have dedicated attention to other cultural and social aspects that mark the life of workers and that can indicate distinctions in their ways of life.

We note that the main distinguishing marks of life today are found in the spaces that contest the dominant capitalist hegemony, in the forms of resistance and organization and in collective experiences that have been constructed by workers. Even if the results of the struggles of the MST or of actions of the FMMC do not reveal a significant change in the life of their militants, they are a rich form of learning of collective organization. The youth and adults, and even the children, learn from early on that only an even more prolonged and stronger struggle would be capable of generating changes.

In various forms and in various parts of the world, men and women have confronted the question of environmental sustainability by establishing territories that become important social laboratories in search of alterna- 
tives. According to Davis (2006), high levels of organization can be found in the suburbs in a wide variety of forms. We have similarly observed tremendous mobilization in the country. According to Wendy Wolford (2010), after an interval of 40 years, agrarian reform is once again present on the global agenda.

Upon considering the urban phenomenon as a global reality that intervenes in the production and relations of production, imposing itself on a global scale, Lefebvre (1971: p. 206) concludes that the urban problem is a revolutionary problem that questions the structures of current society. We observed the massive protests in Brazil in June 2013, which had their epicenter urban problems, especially those related to mobility.

There is no doubt that the urban question can bring together people and groups. Today, more than half of the world population lives in cities and faces all types of problems related to housing, transportation, healthcare, education, violence and many others. Cities are expanding across territories. The growth of suburbs, or of periurban space, in which rural and urban workers coexist, challenges leaders and militants of political parties of the left, unions, and social groups and movements to build a common agenda of struggle. We understand that a dualistic vision impedes a unified organization of the working class.

It is therefore necessary to break with the idealization of the country and rural worker, and abandon the image of a happy and orderly past threatened by outside disorder, which serves to hide and escape from the implacable contradictions of our time. The image of the countryside as the past and the city as the future, as isolated terms, leaves us in an indefinite present, according to Williams (1973).

At the foundation of new social needs and antagonisms in the country and the city, there are the possibilities for building a new and superior synthesis between agriculture and industry and between country and city.

\section{References}

Bernstein, H. (2012). Agriculture/Industry, Rural/Urban, Peasants/Workers: Some Reflections on Poverty, Persistence and Change. International Workshop on Poverty and Persistence of the Peasantry, University of Bergen and El Colegio de México, México City, 13-15 March 2012, 1-27.

Breman, J. (2009). Myth of the Global Safety Net. New Left Review, 59, 29-36.

Brenner, N., \& Elden, S. (2009). Henri Lefebvre on State, Space, Territory. International Political Sociology, 3, $353-377$. http://dx.doi.org/10.1111/j.1749-5687.2009.00081.x

Dantas, J.S. (2012). Espaços Coletivos de Esperança: a Experiência Política e Pedagógica da Comissão de Educação do Fórum do Maciço do Morro da Cruz em Florianópolis/SC. Tese (Doutorado em Educação), Florianópolis: Universidade Federal de Santa Catarina.

Davis, M. (2006). Planeta Favela. São Paulo: Boitempo.

Davis, M. (2004). Planet of Slums. New Left Review, 26, 5-35.

Elden, S. (2010). Land, Terrain, Territory. Progress in Human Geography, 34, 799-817. http://dx.doi.org/10.1177/0309132510362603

Engels, F. (2009). The Condition of the Working Class in England. Oxford: Oxford University Press.

Germer, C. (2007). O Sentido Histórico da Reforma Agrária como Processo de Redistribuição da Terra e da Riqueza. Abra, 34.

Harvey, D. (2012). Rebel Cities: From the Right to the City to the Urban Revolution. London and New York: Verso.

Harvey, D. (2004). Espaços de Esperança. São Paulo: Loyola.

Harvey, D. (1996). Justice, Nature, and the Geography of Difference. Cambridge and Oxford: Blackwell Publishers.

Hobsbawm, E. (1991). A Era das Revoluções. Rio de Janeiro: Editora Paz e Terra.

Hutchison, R. (2009). Right to the City. In Encyclopedia of Urban Studies (pp. 1-10). Thousand Oaks, CA: SAGE Publications, Inc.

Hutchison, R. (2009). Urban Life. In Encyclopedia of Urban Studies (pp. 1-5). Thousand Oaks, CA: SAGE Publications, Inc.

Janata, N. E. (2012). “Juventude que Ousa Lutar!”: Trabalho, Educação e Militância de Jovens Assentados do MST. Tese (Doutorado em Educação), Florianópolis: Universidade Federal de Santa Catarina.

Lefebvre, H. (1991). The Production of Space. Oxford and Cambridge: Blackwell Publishers.

Lefebvre, H. (1971). De lo Rural a lo Urbano. Barcelona: Ediciones Península.

Lichter, D., \& Brown, D. (2011). Rural America in an Urban Society: Changing Spatial and Social Boundaries. Annual Review of Sociology, 37, 565-592. http://dx.doi.org/10.1146/annurev-soc-081309-150208

Maricato, E. (2006). Posfácio. In M. Davis (Ed.), Planeta Favela (pp. 209-224). São Paulo: Boitempo. 
MST-Movimento dos Trabalhadores Rurais Sem Terra (2005). Método de Trabalho e Organização Popular. São Paulo: Setor de Formação.

OIT (2001). Trabalho Infantil No Brasil. http://www.ilo.org/

Oliveira, A. U. (1994). O Campo Brasileiro no Final dos Anos 80. In J. P. Stédile (Ed.), A Questão Agrária Hoje (pp. 45-67). Porto Alegre: Editora da UFRGS.

Quaini, M. (1979). Marxismo e Geografia. Rio de Janeiro: Paz e Terra.

Rego, T. T. (2011). A Formação Técnico-Profissional em Agroecologia no MST/SP. Dissertação (Mestrado em Educação), Florianópolis: Universidade Federal de Santa Catarina.

Santos, M. (2006). A Natureza do Espaço: Técnica e Tempo, Razão e Emoção. São Paulo: Editora da USP.

Santos, M. (1994). A Urbanização Brasileira. São Paulo: Hucitec.

Sapelli, M. L. S. (2013). Escola do Campo-Espaço de Disputa e de Contradição: Análise da Proposta Pedagógica das Escolas Itinerantes do Paraná e do Colégio Imperatriz Dona Leopoldina. Tese (Doutorado em Educação), Florianópolis: Universidade Federal de Santa Catarina.

Smith, R. (1997). Creative Destruction: Capitalist Development and China’s Environment. New Left Review, 222 , 3-41.

Vilar, P. (1985). Economia Camponesa? In P. Vilar (Ed.), Iniciação ao Vocabulário da Análise Histórica (pp. 253-303). Lisboa: Edições João Sá da Costa.

Williams, R. (1973). The Country and the City. Oxford: Oxford University Press.

Wolford, W. W. (2010). This Land Is Ours Now: Social Mobilization and the Meanings of Land in Brazil. Durham: Duke University Press. http://dx.doi.org/10.1215/9780822391074 